تأثير الأساليب الإخراجية للصحف الدينية الإسلامية المصرية على تذكر المعلومات الدينية في إطار نظرية تمثيل المعلومات

$$
\text { دراسة شبة تجريبية على عينة من طلاب الجامعة }
$$

إعداد الباحثة:

$$
\text { زينب عبد الوهاب صالح }
$$

مقدمة:

يعتقـــــ أن للبنـاء الشــكلي للصــحيفة دوره الرئيسـي في عمليـة جـــب انتبــاه القـارئ إلى الصـحيفة ومحتـواه، فالصـحيفة في الأسـاس منـتج بصـري يعتمـــ في تصـميمه مـن جانـب المخـرج الصـحفي وفن تلقيـه مـن جانـب القـارئ على حاسـة البصـر، والـتي إن نجـح التصـميم في الاسـتحواذ عليهـا بـــأت سلسـلة أخسرى مـن العمليــات العقليـة لإضفاء المعاني على ما يراه القراء(1).

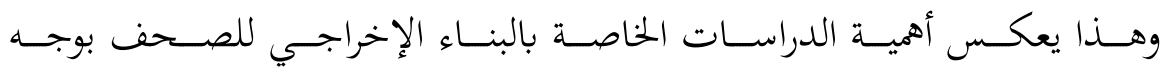
عـام والصـحف الإسـلامية بوجـهـ خـاص في علاقتهـا بالتمثيـل المعـرفي وعمليـة تـذكر

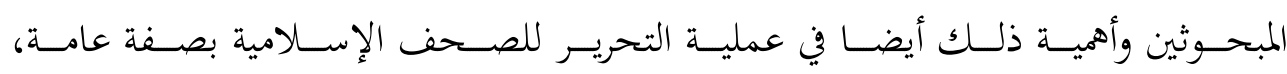
والإخراج بصفة خاصة للقيام بوظائفها وتحقيق أهدافها.

\title{
مشكلة الدراسة :
}

تسـعى هـــه الدراســة إلى اختبـار تأثـير أسـاليب إخــراج العناصـر التيبوغرافيـة

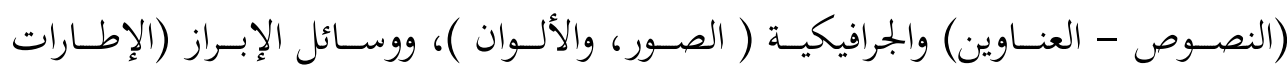

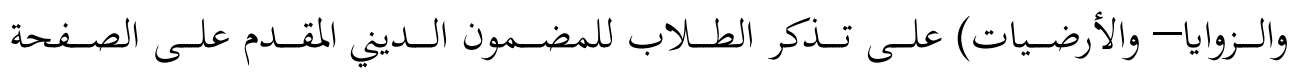

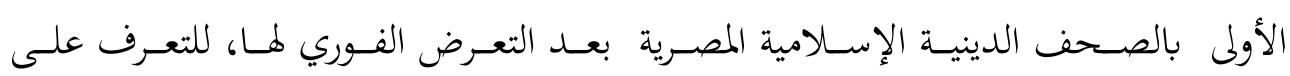
مدى تأثير المتغير المستقل (العناصر الإخراجية ) على المتغير التابع (التذكر ) . 
ترجع أهمية الدراسة لما يلي :

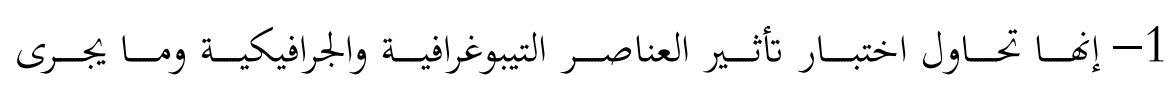

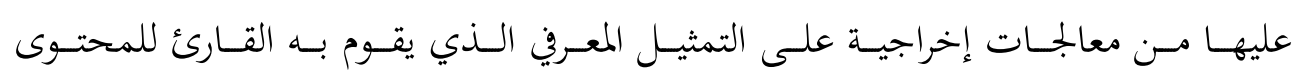
الديني بالصحف الإسلامية.

2- الطبيعـة الماديـة للصـحيفة كوسـيلة بصـرية تتميـز بالبقــاء لفـترة أطسول في

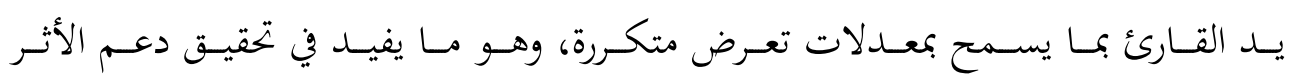

· المعري لما ينشر

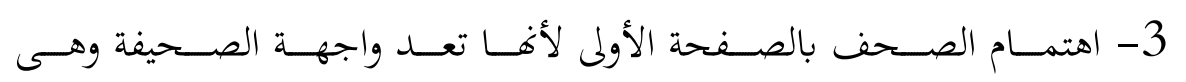

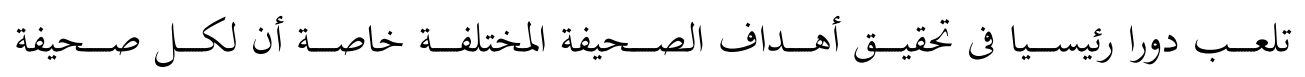
شخصيتها المتميزة التي يهاول الإخراج الصحفي رسمها. أهداف الدراسة:

تهـدف هــذه الدراسـة إلي اختبــار تأثسير أسـاليب إخــراج العناصـر التيبوغرافيـة

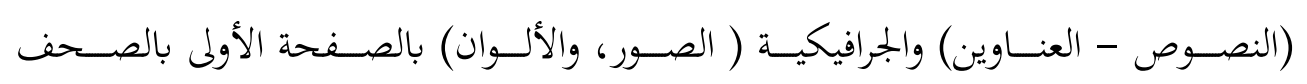

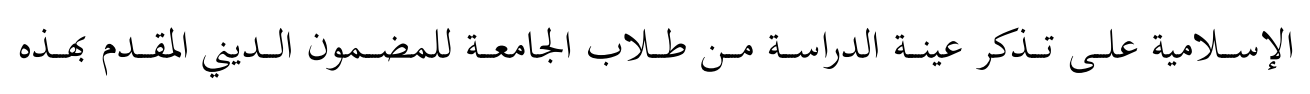
الصفحة . ومن هذا المنطلق تتحدد أهداف الدراسة التجريبية في الآيت : - تحديد أكثر العناصر الإخراجية التي تساعد على تذكر المضمون الديني.

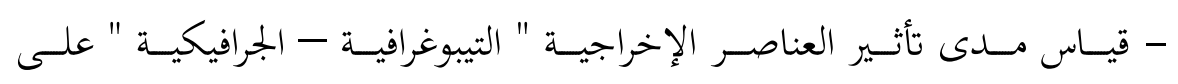
درجات تذكر المبحوثين للمضمون الديني. 
ونسـتعرض فيمـا يلـي أهـم مـا تناولتـهـ الدراســات السـابقة وأدبيــات البحــث

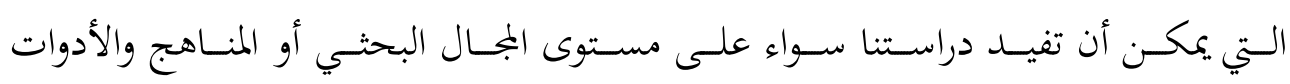
البحثية والإطار المنهجي إلى ثلاثة محاور رئيسي:

المحور الأول: الدراسات التي تناولت الصحف الإسلامية بشكل عام. المحور الثاني: الدراسات التي تناولت إخراج الصفحة الأولى .

المهـور الثالث:الدراسـات الـتي تناولـت تصــميم وإخــراج الصــف و تأثيرهــا

$$
\text { على العمليات الإدراكية (التذكر). }
$$

\section{أولا : الدراسات التي تناولت الصحف الإسلامية بشكل عام:}

- دراسـة الطيـب أحمــ (2008) بعنـوان "إخــراج الصـحف الدينيـة في مصـر، دراسـة تطبيقية على صحيفتي اللواء الإسلامي وعقيدتي"(2): اسـتهدفت هـــه الدراسـة إخــاج الصـحف الدينيـة وبنائهـا الشـكلي، ودراســة العناصـر

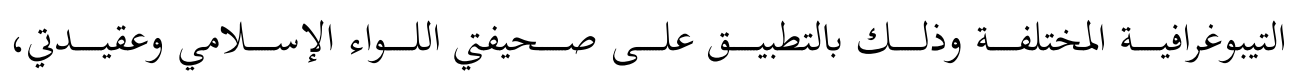
وتوصـلت الدراسـة إلى تفـوق عقيــتي على اللـواء الإسـلامي في اسـتخدام البيـاض بــين

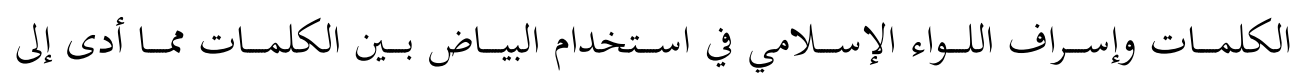
خلق أهمار بياض تعوق القراءة .

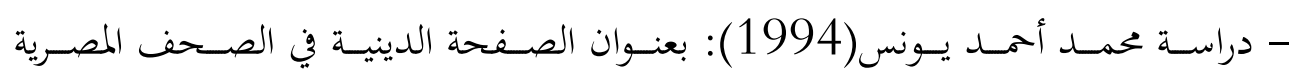

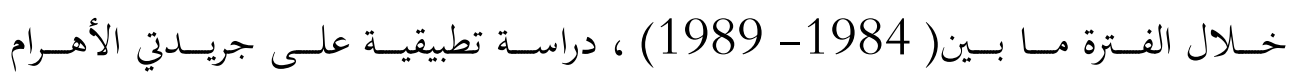

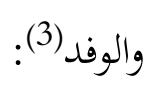

اسـتهلدفت وصـف وتحليـل وتقـويم الصـفحات الدينيـة المتخصصـة في صحيفتي

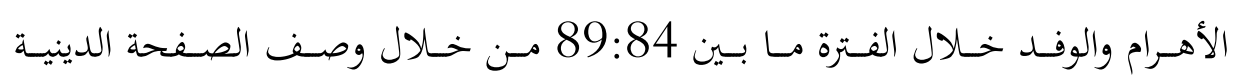

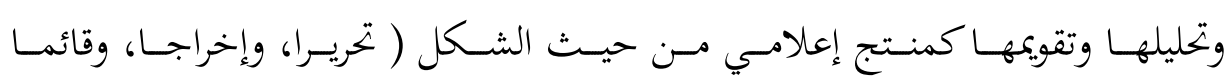


بالاتصــال، وتوصـلت الدراسـة إلى إنـه انعكسـ المضـمون الـــيني الجــاد للصـفحة

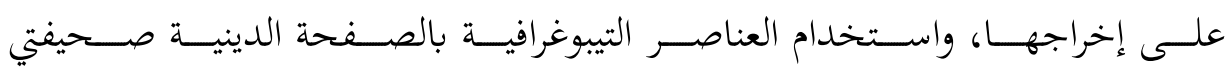
الأهرام والوفد.

\section{ثانيا: الدراسات التى تناولت إخراج الصفحة الأولى:}

- دراسـة محمــود إسماعيـل عبــــ الــرؤف إبـراهيم(2015): بعنـوان " إخـــاج الصـفحة الأولى في الصحف المصرية بعد ثورة 25 يناير"(4):

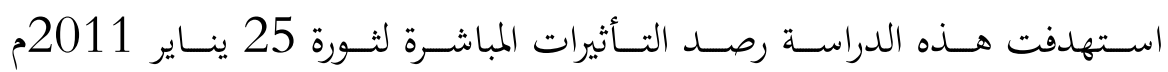

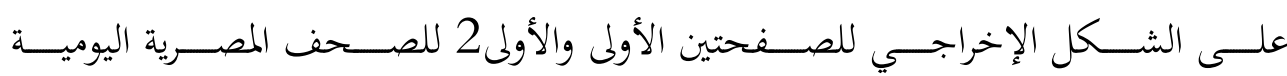

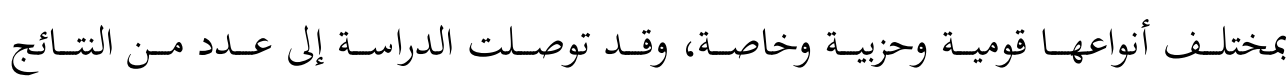

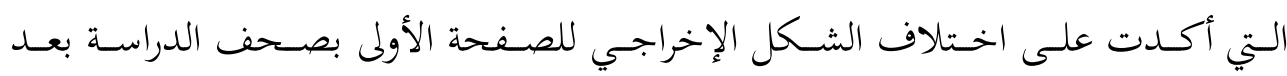
ثــورة 25 ينـاير، ومحاولــة التغلـب علـى الشـكل التقليـدي للصــفحة الأولى وإكســابها شكالا جماليا وجذابا.

- دراســة مصـطفى شـكري(2013): بعنـوان" أثـــــــوع الملكيــة في إخـراج الصـحف

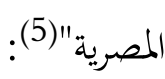

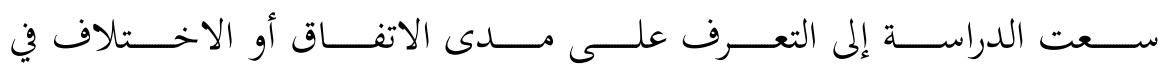

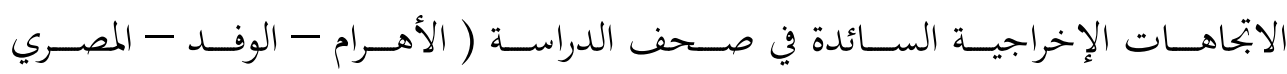

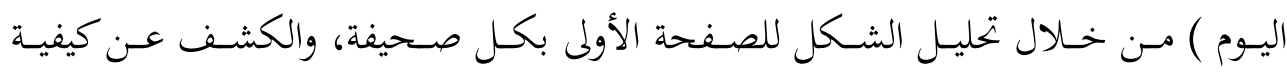

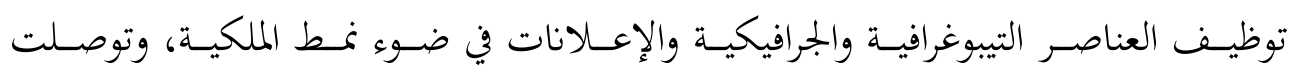

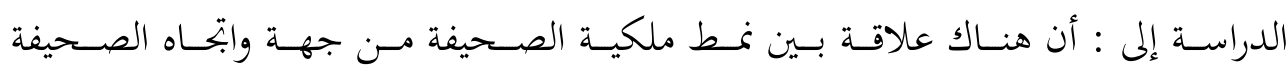
إلى الإثارة الإخراجية من جهة أخرى.

- دراسـة Sandra utt h \& steve pasternack الصفحة الأولي : استمرارية بعض الاتجاهات(6): 


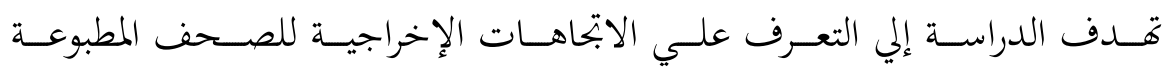

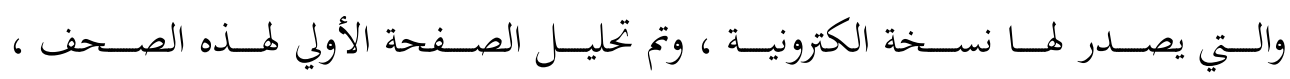

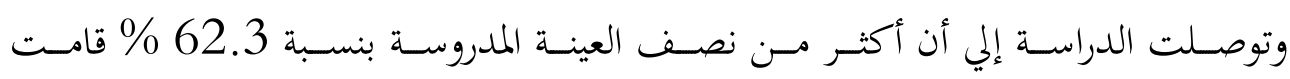
بإعادة إخراج شكل الصفحة الأولي خلال الخمس سنوات الأخيرة . ثالثـا: الدراسـات الـتي تناولـت تصـميم وإخــراج الصـحف و تأثيرهـا علـى العمليـات الإدراكية (الثذكر):

- دراســة محمــد عبــد الله حسـين عبــد الله (2014) : " العوامـل المـؤثرة في فهـم وتذكر الصم للمعلومات المقدمة بالبرامج المتزجمة بلغة الإشارة"(7): تسـتهدف التعـرف على تأثنير المـواد المرئيسة على فهـم وتـذكر الصـم للمعلومـات

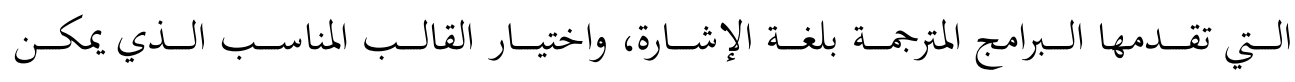

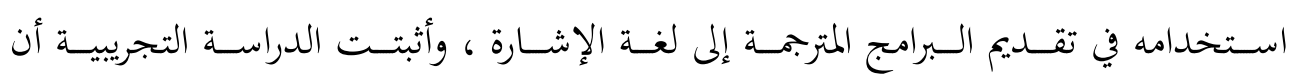
المؤثرات المرئية التي تأتي في فاية المادة المقدمة تلعب دورا في تذكر المادة المقدمة. - دراسـة أسمـاء عبـد الحكـيم محمــد عبــد اللطيـف(2012): " اسـتخدام الطـلاب

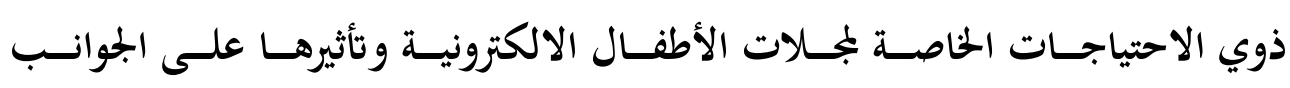
المعرفية لديهم" (8) - (8) - (8) هـــف الدراسـة إلى التعـرف على تأثـير الوسـائط المتعــدة مثـل الـنص والصـورة

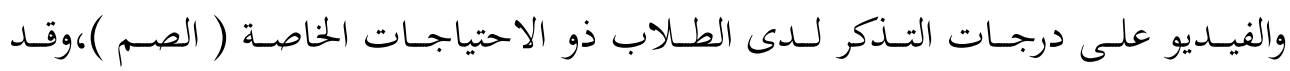

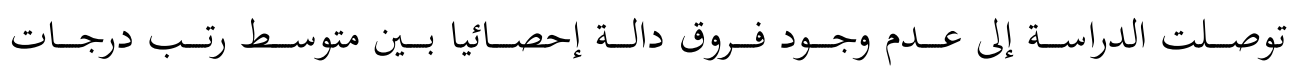
مجموعسة (الـنص فقـط) ومتوسـط رتسب درجـات مجموعـة( الـنص + الصـورة ) أي أنسه يوجد تقارب بين متوسطي رتب درجات هاتين المجموعتين في درجات التذكر. - دراسة huitt . w (2003) بعنوان : معالجة المعلومات إلي الإدراك (9). 
تناولـت هـذه الدراسـة نظريـة تمثيـل المعلومــات وعرضـت لأهـم الأطــر والنمـاذج

هــذه النظريــة نمـوذج إتكســنون وشـيفرين 1968 نمسوذج كريسك لـو كهـارت 1972

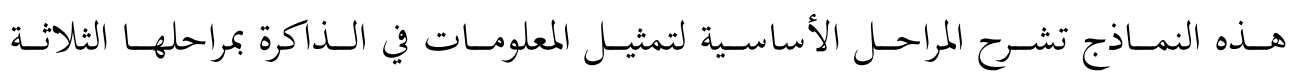

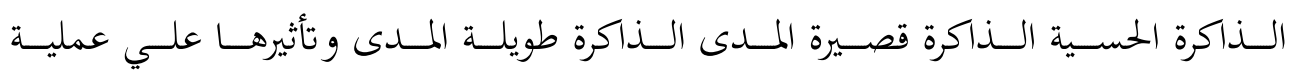
التذكر التي تتم من خلال التمثيل الصحيح للمعلومات.

35- دراسـة Burrell David Kingery (2000) : بعنـوان : تحليـل عناصـر الطباعة الرقمية لعناوين الصحف الالكترونية وتخطيط الصفحة(10):

اسـتهدفت الدراسـة التعـرف علـي تأتشير تصـميم عنـاوين الصـحف الالكترونيـة

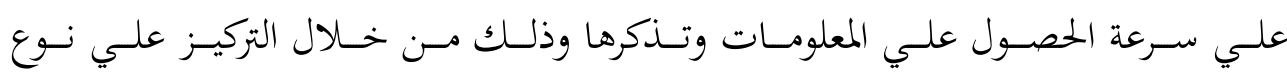

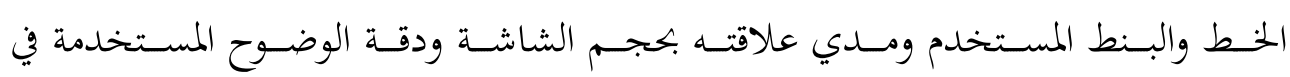

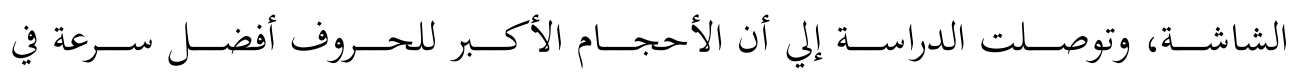
الحصول علي المعلومات.

\section{أوجه القصور والاستفادة من الدراسات السابقة:}

وقــــــــفادت الباحثــة مــن الدراســات والبحــوث الســابقة في الجوانسب

التالية:

- تحديد المشكلة البحثية وتحديد درجة أهميتها . - توجيه فروض الدراسة الحالية. - تحديد وبناء أدوات الدراسة الحالية. - الاسترشـاد إلى المراجـع والمصــادر الـتي اسـتعانت كـــا الدراســات الســابقة والاستفادة منها قدر الإمكان. 


\section{فروض الدراسة:}

في ضوء صياغة المشكلة البحثية وفن ضوء ما سبق من دراسات سابقة تسعى هذه الدراسة إلى اختبار مجموعة من الفروض، ويتمثل الفرض الرئيسى فيما يلى: " توجد فروق ذات دلالة إحصائية في درجات تذكر المبحوثين للمضمون الدينى

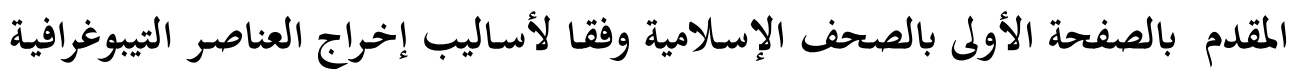
والجرافيكية المصاحبة لهذا المضمون". وينبع من هذا الفرض، عدة فروض على النحو التالى :

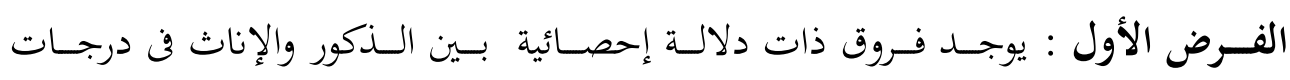

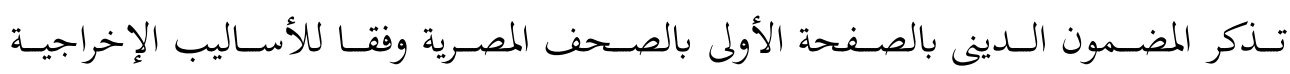

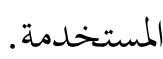

الفـرض الثـانف : يوجـــ فـروق دالـة إحصـائيا في درجـات التــكر للمحتـوى الـديني المقــدم بالصـحف الدينيـة الإســلامية بــين الأسـاليب الإخراجيــة المسـتخدمة (العنـاوين

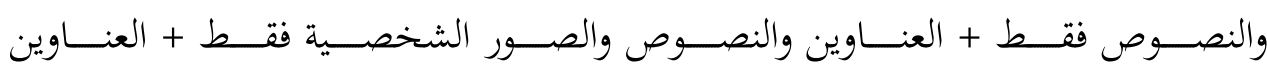

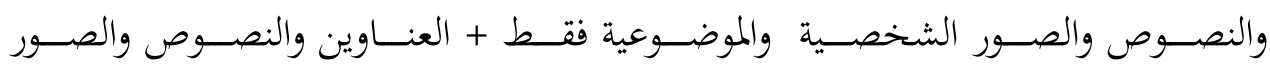

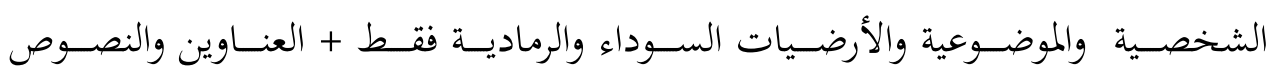

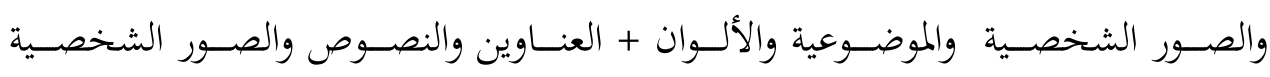
والموضوعية والألوان والإطارات والزوايا).

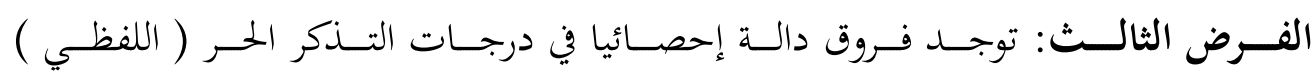

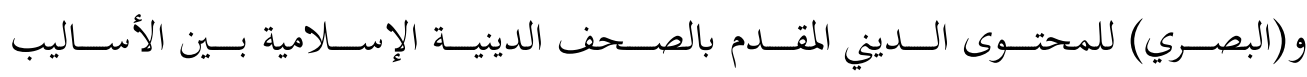

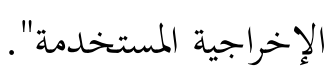




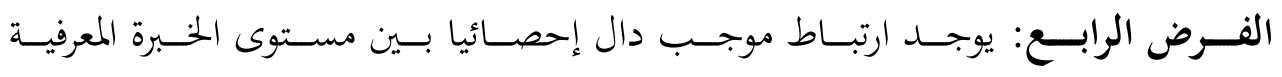

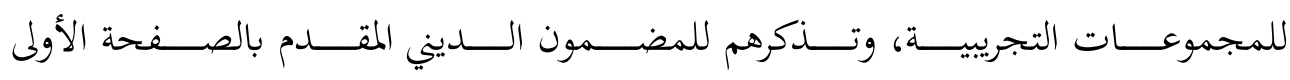
بالصحف الإسلامية وفقا لتأثير الأساليب الإخراجية المستخدمة.

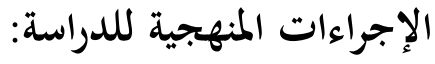

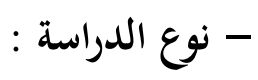

تعد هذه الدراسة من الدراسات شبه التجريبية التي قتتم بالتوصل إلى الاستنتاجات

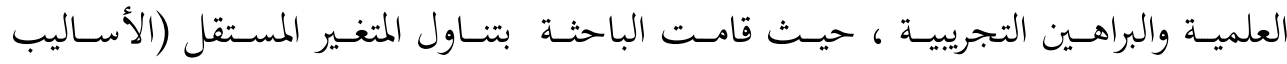

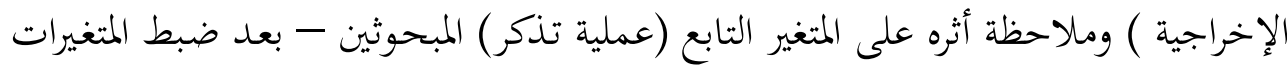

والعوامل الأخرى التي يمكن أن يكون لها علاقة بالظاهرة

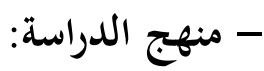

تعتمد الدراسة على المنهج التجريبي، حيث تنتمي هذه الدراسة إلى فئة البحوث

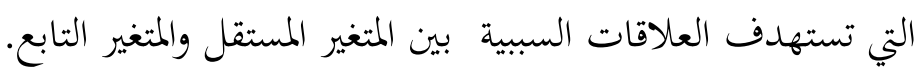

\section{أنصميم التجريبي للدراسة :}

بناء على منهج الدراسة وهو المنهج التجريبي - قامت الباحثة بتقسيم مجموعات

$$
\text { الدراسة إلى ست بمموعات بتريبية. }
$$

بحسب هذا النوع من التجارب قامت الباحثة بقياس تأثير عامل واحد " العامل

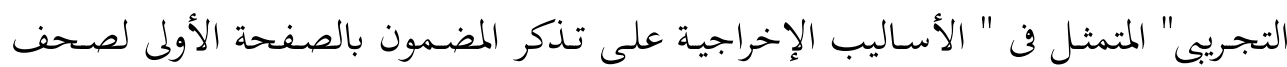

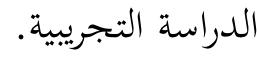




\section{- نوع التصميم التجريبي :}

تستخدم الباحثـة أسـلوب القيـاس البعـدي للمجموعـات التجريبيـة، وبنـاء عليـه تم

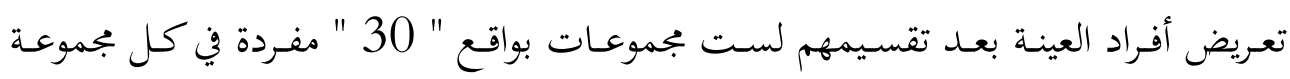
للنماذج التجريبية.

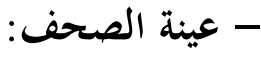

قامست الباحثـة بتصـميم سـت نماذج للصففحة الأولى لصحيفة إسـلامية، تناولـت

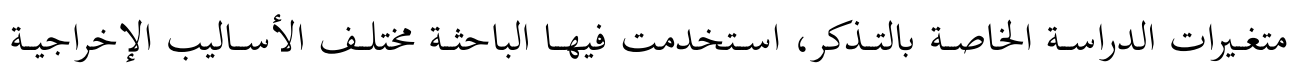
المستخدمة في الدراسة.

النموذج الأول: يكون مبنى على أساس تأثير العناوين والنصوص، النموذج الثاني: بتأثير الصور الشخصية، النموذج الثالث: بتأثير الصور الشخصية والموضوعية ، النموذج الرابع: بتأثير الصسور الشخصية والموضوعية والأرضيات السوداء والرماديـة ، والنمـوذج الحـامس:

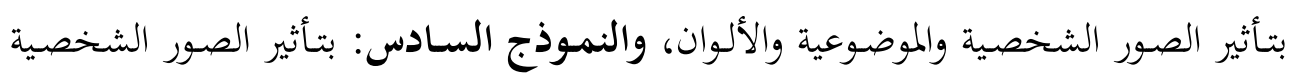
والموضوعية والألوان والإطارات والزوايا.

$$
\text { النماذج التجريبية للدراسة: }
$$

الإنتاء بطالب الدولة بمعاجبة المشعكين في هوابت الديث.
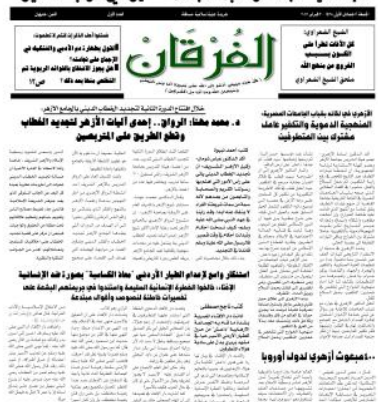

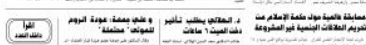

ب0.

(6)

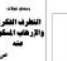

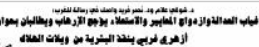

النموذج الثاني

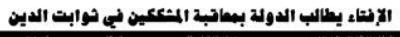
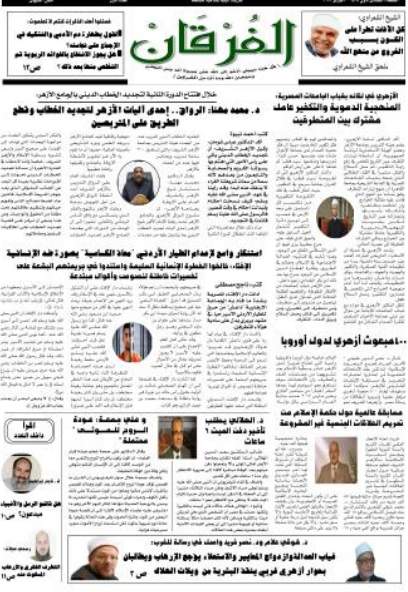

النموذج الأول 
مجموعة العناوين والنصوص والصور الشخصية فقط

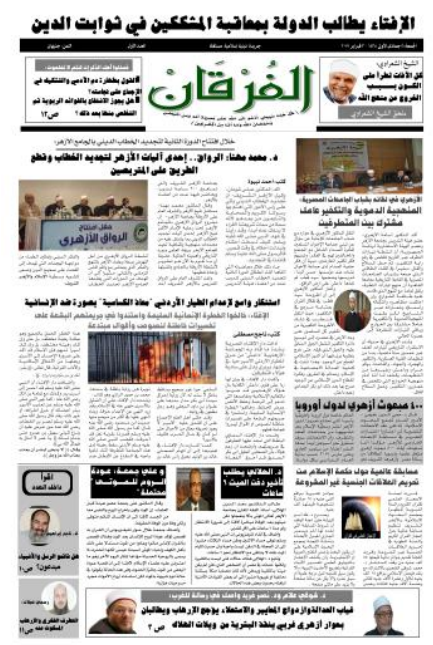

$$
\text { مجموعـة العنـاوين والنصـوص والصـور }
$$

الإنتاء بطالب الثولة بمافبة المشعين في هوابت الدين

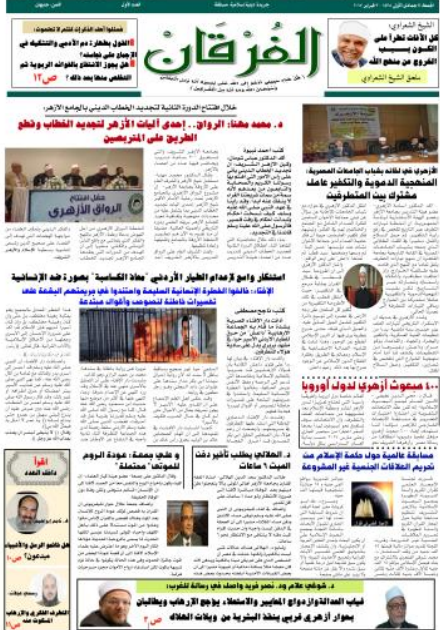

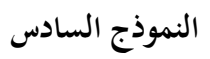

بجموعة العناوين والنصوص والصور

والألوان والإطارات والبراويز
مجموعة العناوين والنصوص فقط

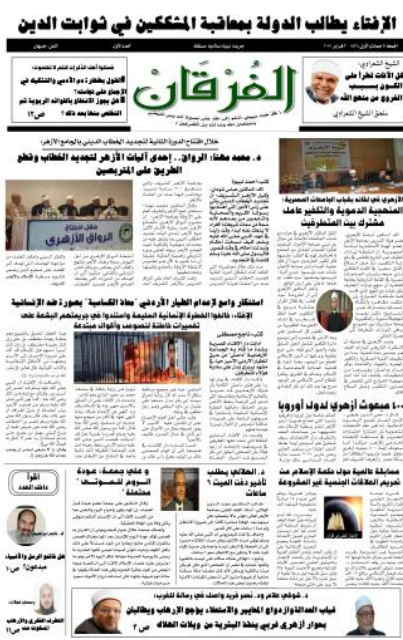

$$
\text { النموذج الثالث }
$$

$$
\text { مجموعــة العنـاوين والنصـوص }
$$

والصور الشخصية والموضوعية فقط

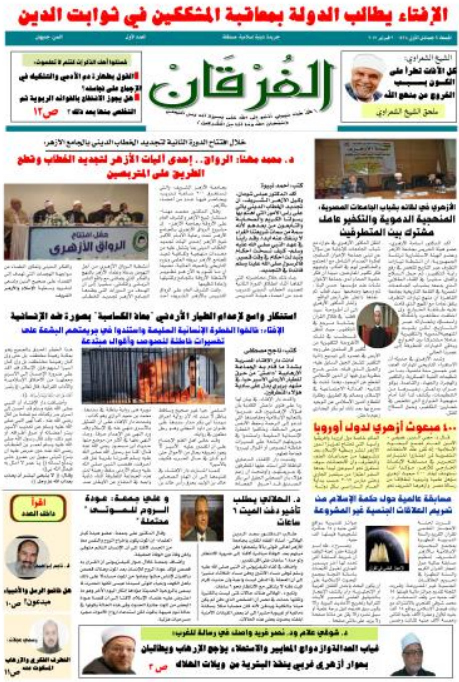

$$
\text { النموذج الخامس }
$$

مجموعة العناوين والنصوص والصور والألوان 
وقع اختيار الباحثة على طلاب- قسم علم نفس بكلية الآداب جامعة أسيوط

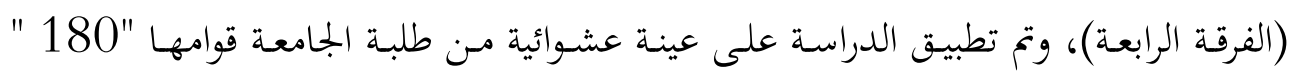

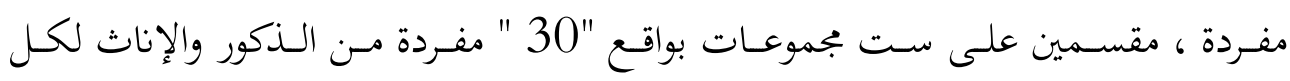
بجموعة.

واعتمدت الدراسة على بناء مقياس للتذكر لكل صحيفة من صحف الدراسة على حـدة تشتمل على الجوانب الأساسية للدراسة يـدون فيها المبحوثين الاستجابات معيل المرتبطة

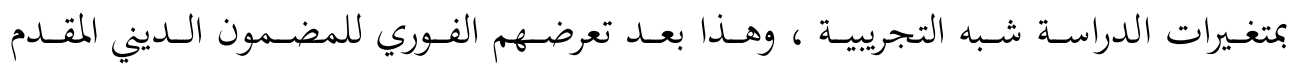
بالصحف محل الدراسة ، وتم توظيفها على هيئة أسئلة لجمع البيانات المطلوبة من مفردات العينة.

\section{متغيرات الدراسة : مت \\ -}

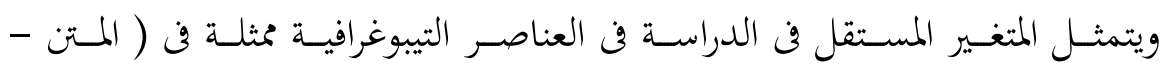

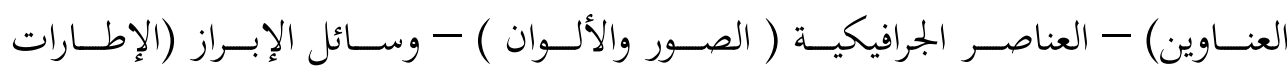

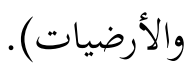

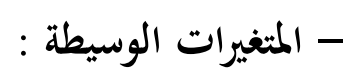

وتتمثل فن الدراسة: النوع ، الخلفية المعرفية.

$$
\text { - المتغير التابع : }
$$

ويتمثل المتغير التابع فن الدراسة: في عملية التذكر". 
لضـبط المقيـاس قامـت الباحثـة بعـرض الصـورة الأوليـة للمقيـاس على مجموعـة مـن

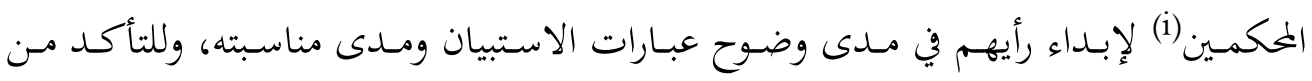

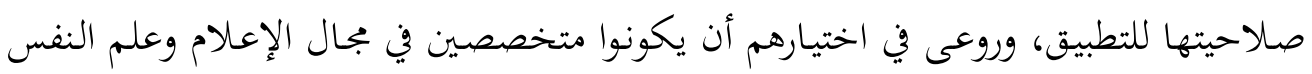
والإخراج الصحفي.

= اختبار الثبات:الثبات: هو أداة جمع المعلومات والبيانات للتأكد من درجة الاتساق العالية لها بمـا يتسيح قيـاس مـا تقيسـه مـن ظـاهرات ومتغـيرات بلدرجـة عاليـة مـن الدقـة، أو متشــابهة إذا تكـرر استخدامها أكثر من مرة في جمع نفس المعلومات أو في قياس نفس الظاهرات أو المتغيرات. ومن هنا قامت الباحثة باستخدام معامل ألفاكرونياخ للتأكد من ثبات المقياس، وجاءت نسبة الثبات مرتفعة عن (73\%) بما يؤكد الثقة في إجابات مفردات الدراسة.

\section{المعالجة الإحصائية للبيانات:}

بعــ الانتهـاء مـن تطبيـق الدراسـة التجريبيـة، تمـت مراجعـة البيـانات السواردة في اسـتمارة

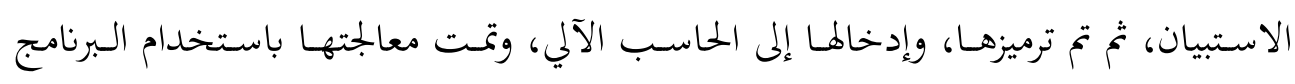
الإحصائي ( SPSS) لإجراء التحليلات الإحصائية المناسبة.

نتائج اختبار صحة فروض الدراسة:

تعـرض الباحثـة في هـذا الجـزء نتـائج اختبـار صـحة الفـروض التي تسعى الدراسـة

$$
\begin{aligned}
& \text { إلى التأكد من صحتها. } \\
& \text { الفرض الأول: }
\end{aligned}
$$

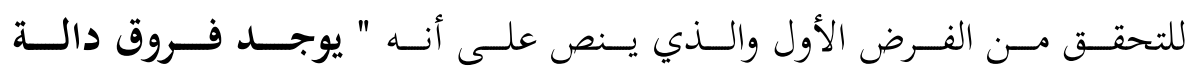

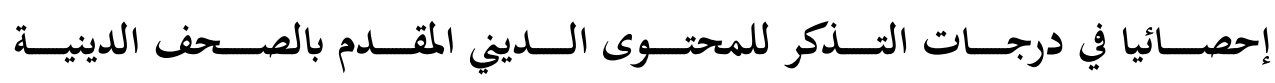
الإسلامية بين الطلاب والطالبات". 
تم اسـتخدام اختبـار "ت" (T. Test) لحســاب الفـروق بـين مجمسوعتي (الطـلاب

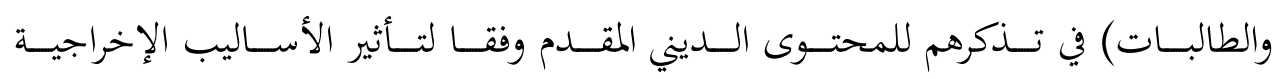

وجاءت النتائج كما بالجدول (1).

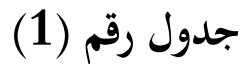

يوضح قيمة (ت) لدلالة الفروق بين متوسطي درجات تذكر الطلاب للمضمون الديني بالصحف الدينية الإسلامية ( ن = 180 )

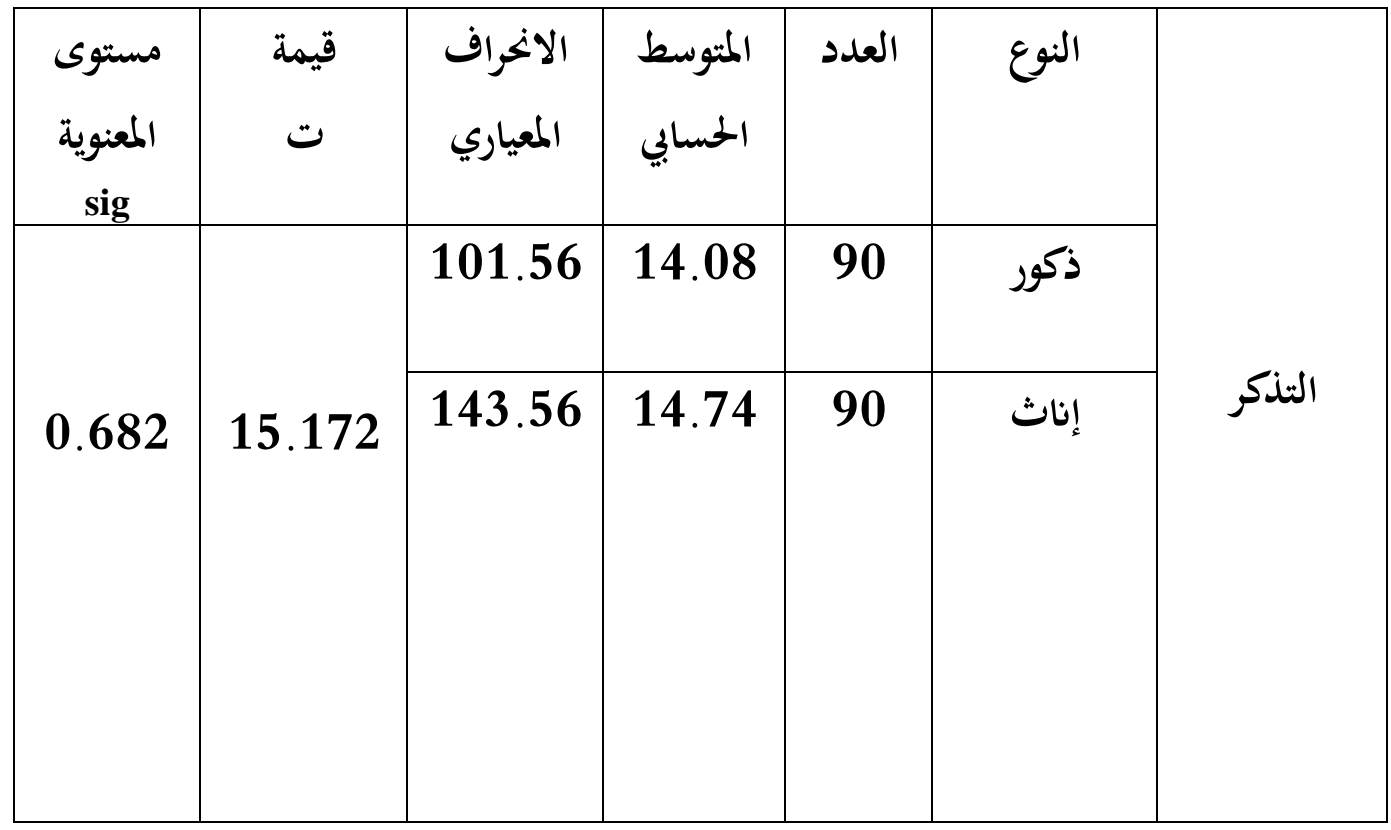

يتضح من الجحدول السابق:

وجـود فـروق دالـة إحصـائيا بــن المبحــوثين مـن الـذكور والإناث فيمـا يتعلـق بدرجـــ

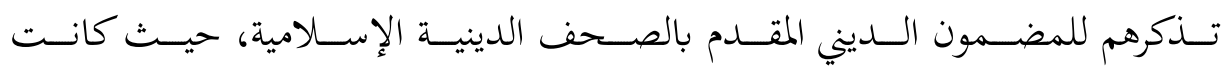

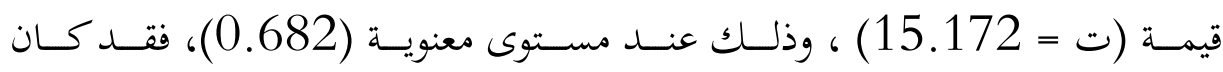

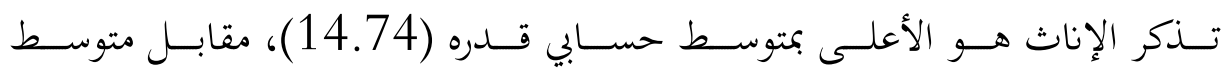

حسابي قدره (14.08) للذكور وهو فرق دال إحصائيا.

أي أن الفرض تحقق كليا، ويمكن تفسير نتيجة اختبار الفرض: 
والـتي أظهـرت وجـود فـروق معنويــة دالـهـ بــن الطـلاب والطالبـات في تــكرهم

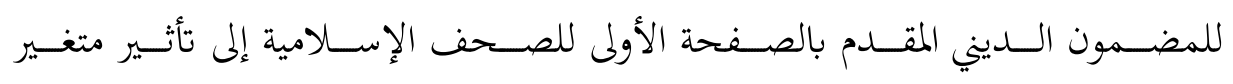

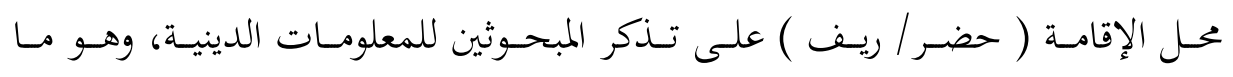

يوضحه نتائج الجدول التالي(2).

جدول رقم (2) - (2)

يوضح قيمة (ت) لدلالة الفروق بين متوسطي درجات تذكر الطلاب للمضمون الديني

بالصحف الدينية الإسلامية ( ن = 180 )

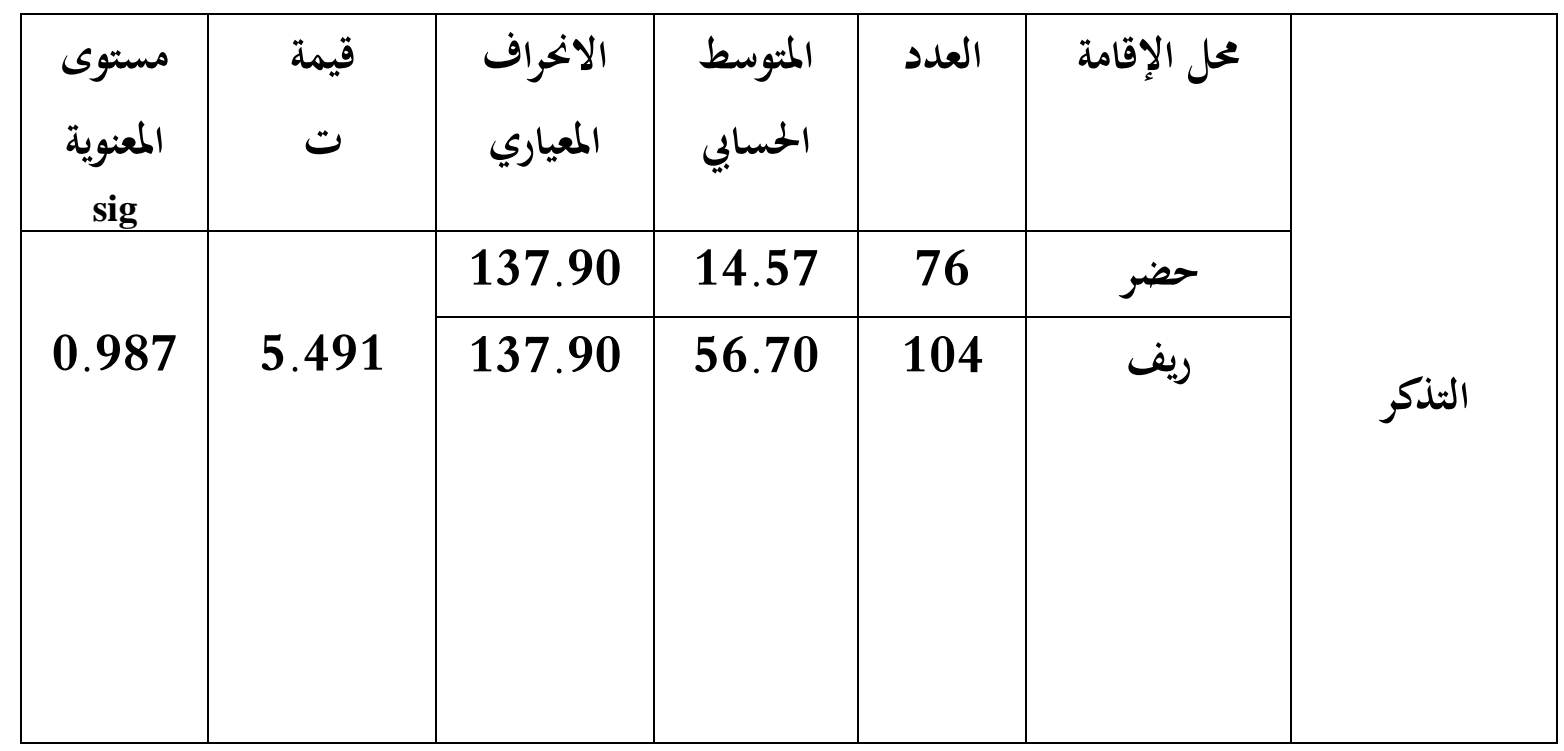

يتضح من الجدول السابق:

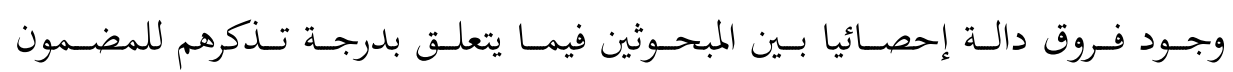

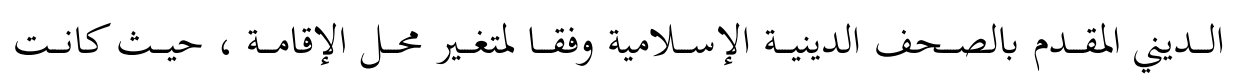

قيمة (ت = 5.491) ، وذلك عند مستوى معنوية (0.987).

الفرض الثاني:

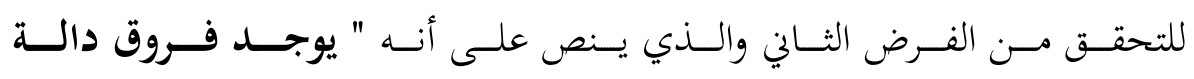

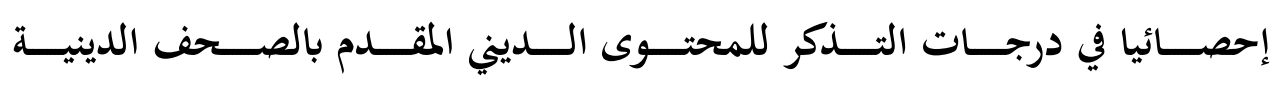


الإســلامية بــين الأسـاليب الإخراجيـة المســتخدمة (العنــاوين والنصـوص فقــ + العنـاوين والنصــوص والصــور الشخصـية فقــ + العنـاوين والنصــوص والصــور

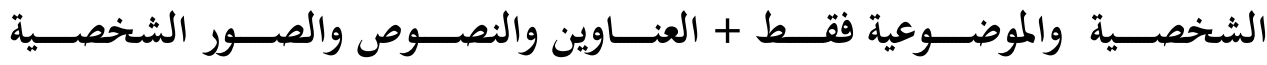

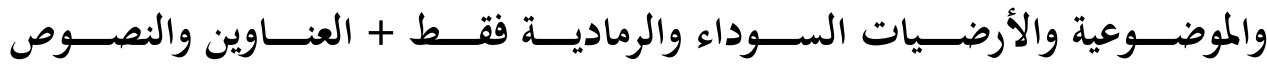
والصـــور الشخصــية والموضــوعية والألــوان + العنــاوين والنصــوص والصـــور الثخصية والموضوعية والألوان والإطارات والزوايا).

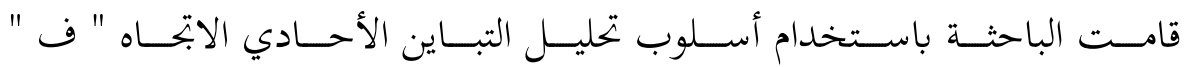
(Main ـــ سـت مجموعـات ( Effect.ANOVA) كما بالجدول (3).

جدول رقم (3) - (3) - (3)

يوضح قيمة (ف) ودلالتها الإحصائية لتأثير الأساليب الإخراجية على درجات تذكر المضمون الديني بالصحف الدينية الإسلامية ( ن = 180 :

\begin{tabular}{|c|c|c|c|c|c|c|}
\hline مربع إيتا & $\begin{array}{c}\text { مستوى المعنوية } \\
\text { sig }\end{array}$ & "فيمة & متوسط المربعات & $\tau .2$ & مجموع المربعات & مصدر التباين \\
\hline \multirow[t]{3}{*}{0.462} & \multirow[t]{3}{*}{0.001} & \multirow[t]{3}{*}{ "6.263 } & 2914.701 & 4 & 11658.806 & 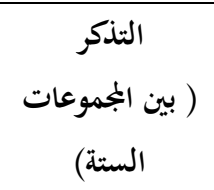 \\
\hline & & & 463.882 & 175 & 11597.061 & 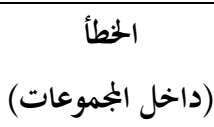 \\
\hline & & & & 179 & 23255.867 & الكلي \\
\hline
\end{tabular}

*عند مستوى ثقة يتضح من الجدول السابق: 
وجـود فـروق ذات دلالــة إحصـائية بــين متوسـطات درجــات أفـراد العينـة باخـتلاف المجموعـات التجريبيـة في مسـتوى التـذكر، حيـثث كانست قيمــة ( ف = 6.263 ) دالة عند مستوى 0.001. أي أن الفرض تحقق كليا.

اللتحقق من الفرض الثالث: التذكر الحر ( اللفظي والبصري ) للمحتوى الديني المقدم بالصحف الدينية الإسلامية بين الأساليب الإخراجية المستخدمة".

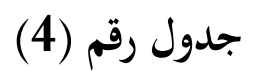
يوضح تحليل التباين بين درجات التذكر الحر ( اللفظي - البصري ) وفقا لتأثير الأساليب الإخراجية في الجمموعات التجريبية الستة: *العلاقة ذات دلالة إحصائية بدرجة ثقة 95\%

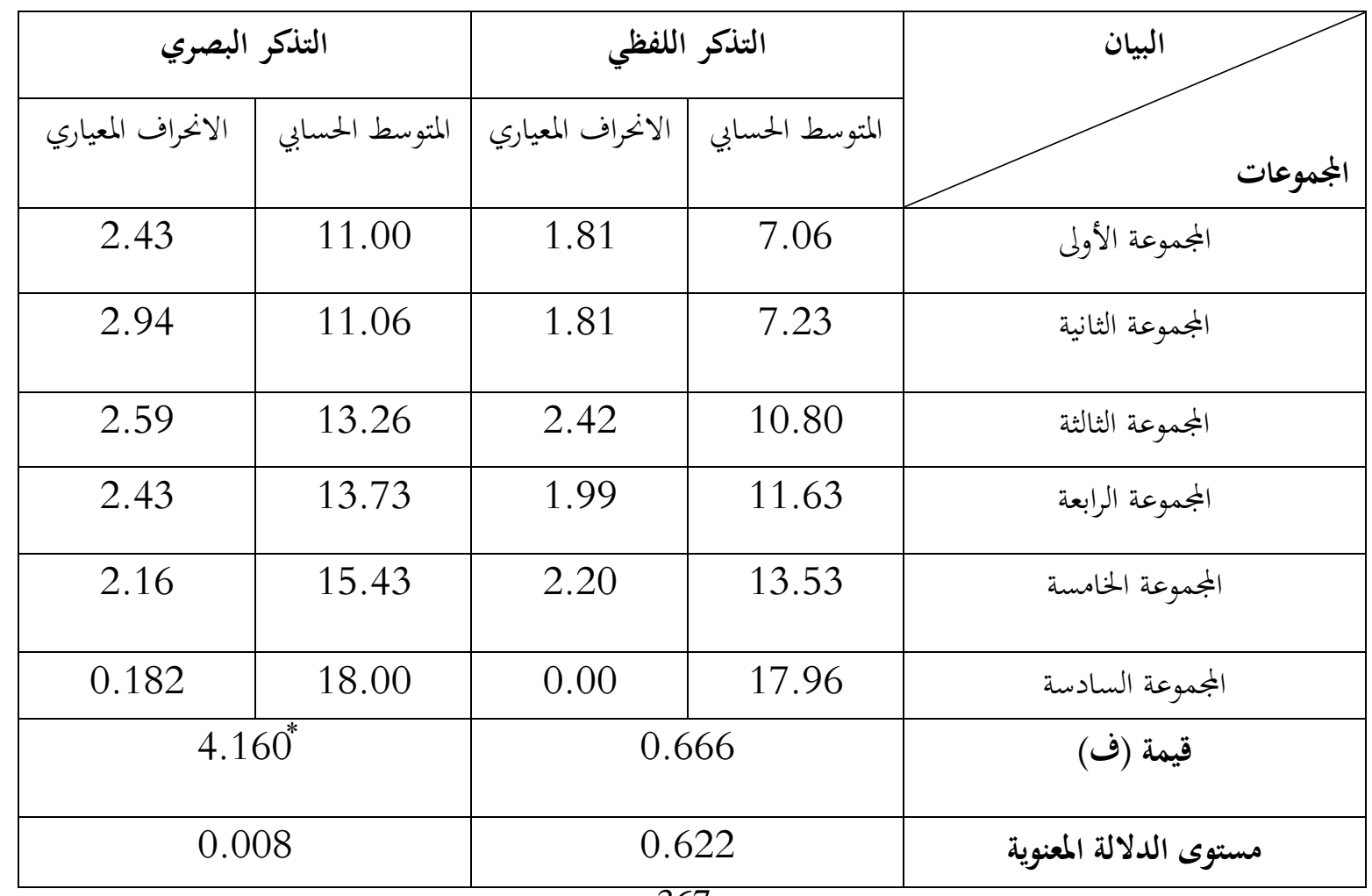


يتضح من خلال الجدول السابق ما يلي:

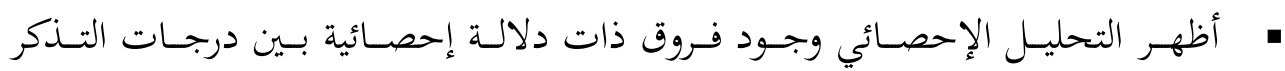

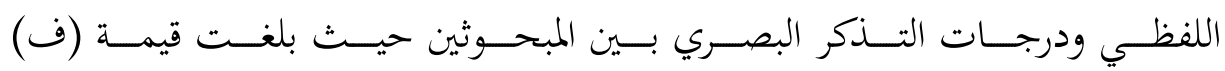

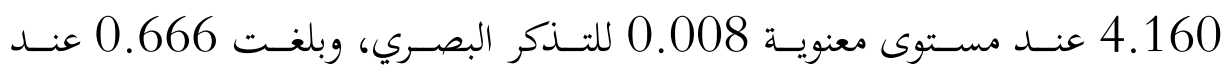

مستوى معنوية 0.622 للتذكر اللفظي.

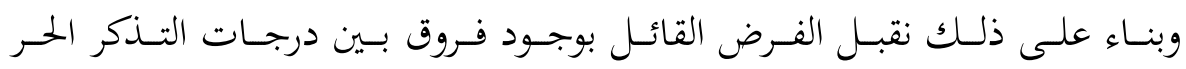

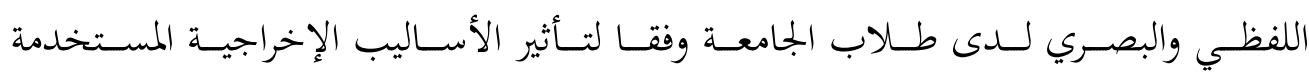

بالصفحة الأولى للصحف الإسلامية.

$$
\text { الفرض الرابع: }
$$

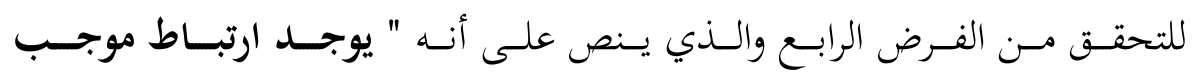

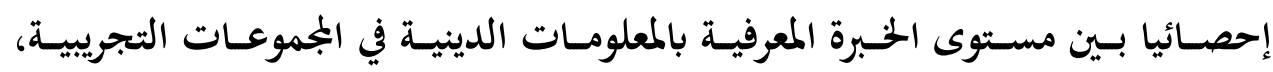

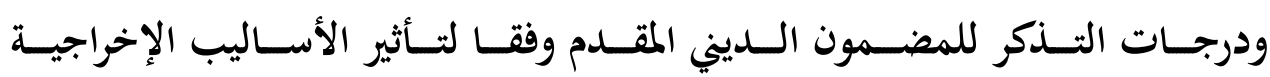

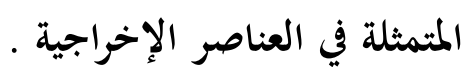

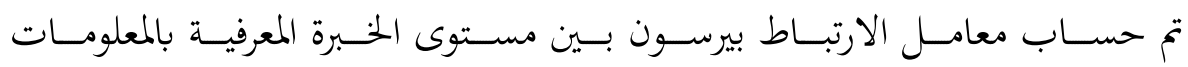

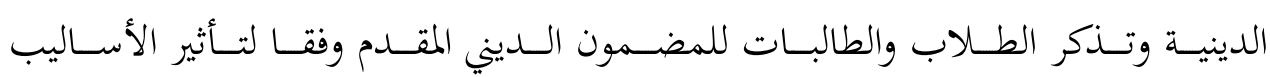

الإخراجية وجاءت النتائج كما بالجدول (5).

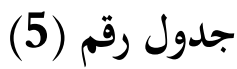

معامل الارتباط بين مستوى الخبرة المعرفية وبين درجات تذكر الطلاب والطالبات

للمضمون الديني المقدم بالصحف الدينية الإسلامية( ن = 180) :

\begin{tabular}{|c|c|c|c|c|}
\hline مستوى الممنوية & معامل الارتباط & الانحراف الممعياري & المتوسط الحسابي & المتغير \\
\hline \multirow[t]{2}{*}{0.005} & \multirow[t]{2}{*}{0.036} & 0.379 & 6.16 & مستوى الخبرة المعرفية \\
\hline & & 24.61 & 4.33 & التذكر \\
\hline
\end{tabular}

يتضح من الجدول السابق : 
عـدم وجـود ارتبـاط دال إحصــائيا بـين الحـبرة المعرفيـة وبـين متوسـط تــكر عينـة الدراسـة للمضـمون الــيني المقــدم بالصـفحة الأولى بالصـحف الدينيـة الإسـلامية، حيــث

$$
\text { كانت (ر) غير دالة عند مستوى } 0.05 .
$$

وبالتــالي نــرفض الفــرض القائــل بوجــود ارتبــاط موجـــب دال إحصــائيا بــين

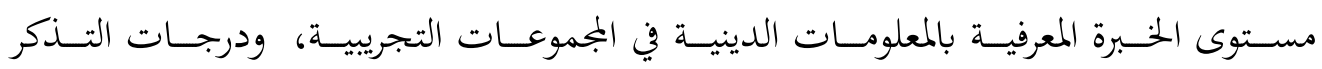

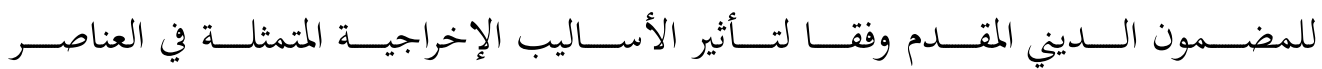
الإخراجية.

\section{النتائج العامة للدراسة:}

- وجـود فـروق دالــة إحصـائيا بــن المبحـوثين مـن الـذكور والإناث فيمـا يتعلـق بدرجة تذكرهم للمضمون الديني المقدم بالصحف الدينية الإسلامية.

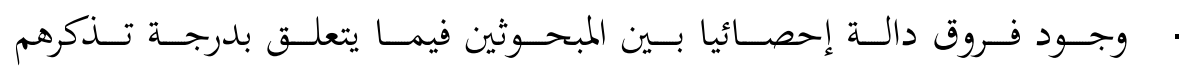

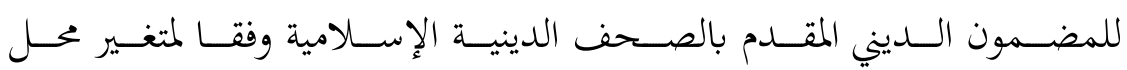
الإقامة. - وجــود فـروق ذات دلالــة إحصــائية بــين متوسـطات درجــات أفـراد العينــة باختلاف المجموعات التجريبية في مستوى التذكر. - أظهـر التحليـل الإحصـائي وجــود فــروق ذات دلالـة إحصـائية بــن درجـات

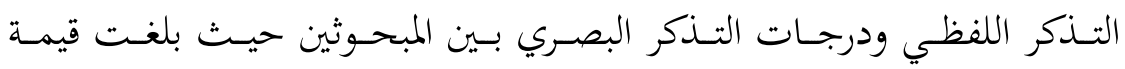

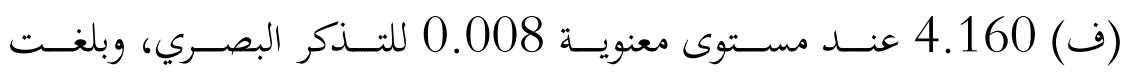
0.666 عند مستوى معنوية 0.622 للتذكر اللفظي.

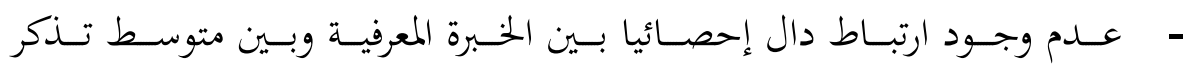

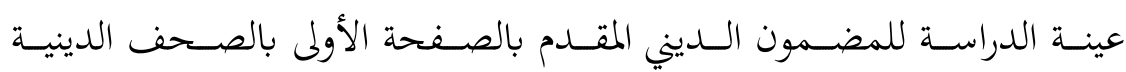

$$
\text { الإسلامية، حيث كانت (ر) غير دالة عند مستوى 0.05. }
$$


- أكـــت الدراســة أن الحــبر المنشــور في الصـحيفة مكتمـل العناصـر (نـصـ

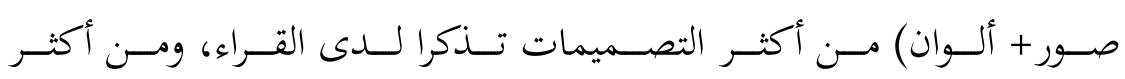

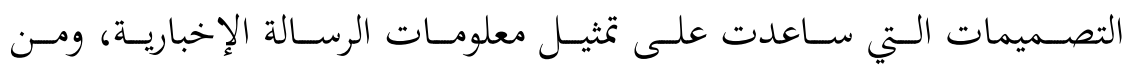

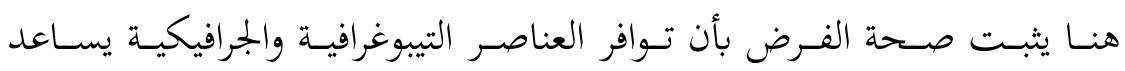

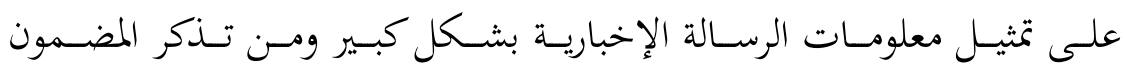
الإعلامي.

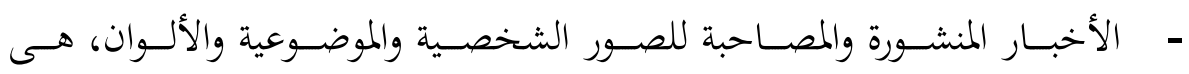

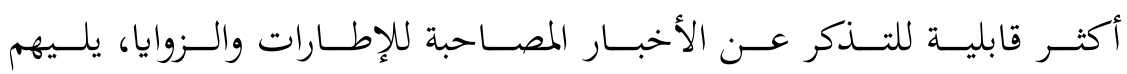

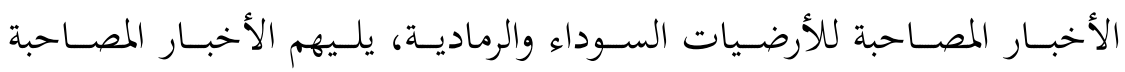

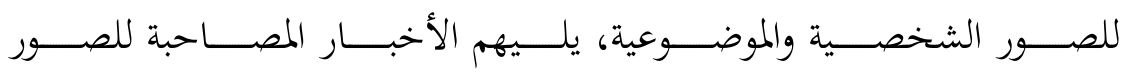
الشخصية، ثم أخيرا الأخبار المصاحبة للنصوص والعناوين.

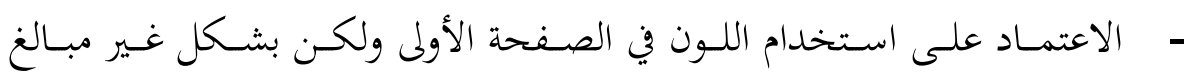

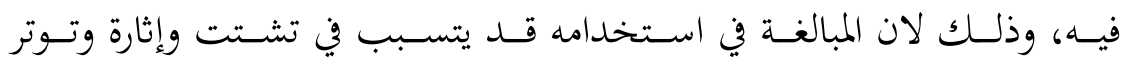

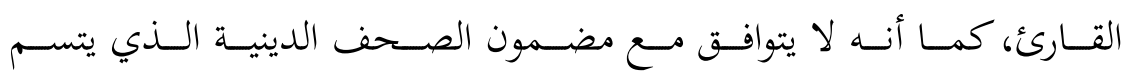
بالززانة والوقار.

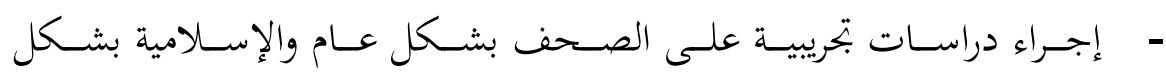
خـاص تختـبر أثثر الشـكل المرئي (التصـميم) على القـارئ مـن خـلال تقـــيم

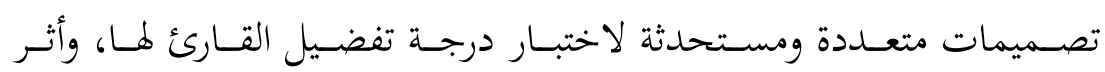
ذلـك على التمثيـل المعـرفي للمـادة الإخباريـة عنـــ مسـتوى الفهـم والانتبـاه والإدراك والتذكر. 


\section{الموامش:}

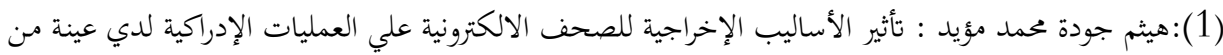

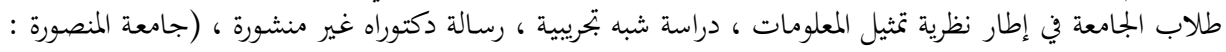
كلية التربية النوعية ، قسم الإعلام التربوي، إطبار نظعل 2010م).

(2):الطيب أحمد محمد : إخراج الصحف الدينية في مصر ، دراسة تطبيقية على صحيفتي اللواء الإسلامي وعقيدتي

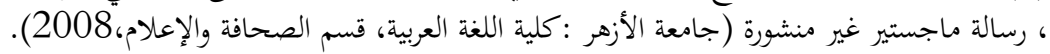

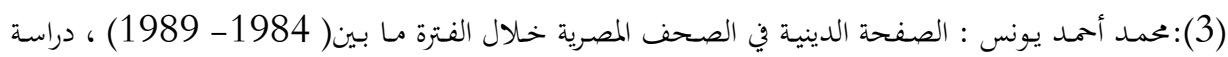

تطبيقة على جريدتي الأهرام والوفد، رسالة ماجستير غير منشورة ( جامعة الصندة القاهرة : كلية إعلام قسم الصحافة ،

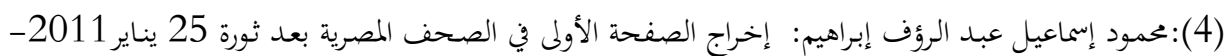

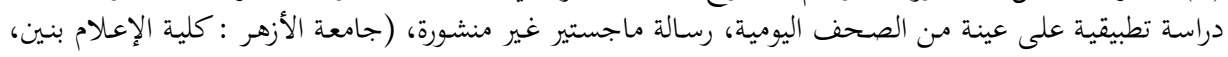
قسم الصحافة والنشر،

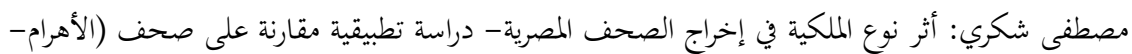

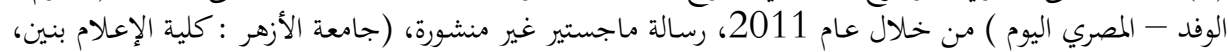
قسم الصحافة والنشر، 2013 2013 ).

6 ): sandrautth.steve pasternack front page design some trends continue newspaper research journal summer 2003 available at http:/www.questia .com /library/1g1-108882756/front- page- designsome- trends- continue

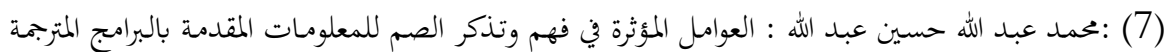

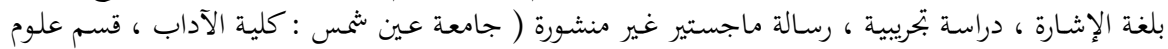
الاتصال والإعلام ، 2014).

(8) : أسماء عبد الحكيم عبد اللطيف: استخدام الطلاب ذوي الاحتياجات المبات الخاصة لمجلات المبات الأطفال الالكترونية

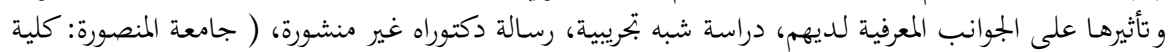
التربية النوعية، قسم الإعلام التربوي، 2012)

9 ): huitt $\mathrm{w}$ the information processing approach to cognition Edcational pstchology interactiveAvailble AT:

10): burrell david kingry an analysis of digital typoghy and pagelayout for headlines in Electronic newspaper Available AT.

http:/sunzi.lib.hku.hk/er/detail/hkul/2699186 


\section{Search title:}

The Influence of the Methods of the Egyptian Islamic Religious Newspapers on the Recall of Religious Information in the Framework of Information Representation

Theory

(A semi-experimental study on a sample of university students)

Prepared by the researcher:

Zeinab Abd El Wahaab Saleh

\section{Research submitted to obtain a Master of Arts degree in media}

\section{Research Summary:}

This study aimed to test the effect of the methods of extracting the typographic elements (texts, titles) and graphics (pictures and colors) on the front page of the Islamic newspapers to remind the sample of the university students of the religious content presented on this page.

the study was divided into six experimental groups to measure the effect of one factor "experimental factor", namely, "the methods of remembering the content on the front page of the experimental study papers.

The researcher used the post-measurement method for the experimental groups. Thus, the subjects were exposed after dividing them into six groups of 30 individual in each group of experimental models. Through this exposure, the researcher discovered the effect of the independent variable, Religious).

Results of the study:The researcher concluded in her study to many results, notably the following:

- There are statistically significant differences between male and female respondents in relation to their degree of religious content presented in Islamic religious newspapers.

- There are statistically significant differences among the respondents regarding their degree of remembrance of the religious content presented in Islamic religious newspapers according to the variable of residence.

- There were statistically significant differences between the average scores of the sample according to the different experimental groups in the level of memory.

- There was no statistically significant correlation between the cognitive experience and the average of the sample of the study of the religious content presented on the first page in Islamic religious newspapers, where ( $t$ ) was not valid at level 0.05 . - The study confirmed that the article published in the newspaper is complete elements (text + pictures + colors) of the most memorable designs to the readers, and the most designs that helped to represent the information of the newsletter, and thus proves the validity of the availability of the elements of typography and graphics helps to represent the information of the message News and a lot of media content. 


$$
\text { i - أ.د أحمد كمال البهنساوي- أستاذ عم النفس المساعد - بقسم علم النفس-بكلية الآداب جامعة أسيوط. }
$$

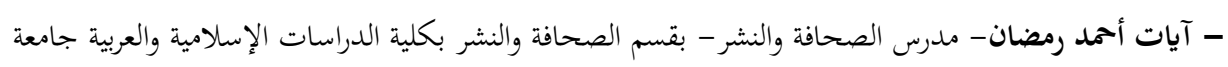
الأزهر.

- دعاء عبد الحكم الصعيدي- مدرس الصحافة والنشر - بقسم الصحافة والنشر بكلية الدراسات الإسلامية والعربية جامعة الأزهر.

- سارة حمدي التيلاوي- مدرس علم النفس- بقسم علم النفس-بكلية الآداب جامعة أسيوط. - أ.د سعيد الغريب- أستاذ الصحافة بقسم الصحافة - بكلية الإعلام جامعة القاهرة. - د. ماجدة محمد عبد الباقي- مدر الصحافة - بقسم الإعلام بكلية الآداب جامعة أسيوط. - أ.د محمود علم الدين- أستاذ الصحافة بقسم الصحافة - بكلية الإعلام جامعة القاهرة. - أ.د منصور إبراهيم المنسي- عميد كلية الفنون الجميلة- بجامعة أسيوط. 